\title{
Can cell proliferation of umbilical cord blood cells reflect environmental exposures?
}

\author{
Lena Novack ${ }^{1,8^{*}}$, Esther Manor ${ }^{1,2}$, Elena Gurevich ${ }^{1,2}$, Maayan Yitshak-Sade ${ }^{1,3}$, Daniella Landau ${ }^{1,4}$, Batia Sarov $^{1}$, \\ Reli Hershkovitz ${ }^{5}$, Doron Dukler ${ }^{6}$, Tali Vodonos ${ }^{1,2}$ and Isabella Karakis ${ }^{1,7}$
}

\begin{abstract}
Environmental hazards were shown to have an impact on cell proliferation (CP). We investigated CP of lymphocytes in umbilical cord blood in relation to prenatal environmental exposures in a sample of 346 Arab-Bedouin women giving birth in a local hospital. Information on subjects' addresses at pregnancy, potential household exposures and demographical status was collected in an interview during hospitalization. This population is usually featured by high rates of neonatal morbidity and multiple environmental exposures, originating from the local industrial park (IP), household hazards and frequent male smoking. A geometric mean CP ratio $2.17(2.06 ; 2.29)$, and was high in women residing in a direction of prevailing winds from the local IP ( $p$ value $=0.094)$ and who gave birth during fall-winter season ( $p$ value $=0.024$ ). Women complaining on disturbing exposure to noise had lower $C P$ ( $p$ value $=0.015$ ), compared to other women. CP was not indicative of neonatal morbidity. However, our findings suggest that CP of umbilical cord might be modified by environmental exposures. A long-term follow-up of the children is required to assess their developmental outcomes.
\end{abstract}

Keywords: Cell proliferation, Environmental exposure, Biomarkers, Pregnancy, Umbilical cord

\section{Introduction}

Environmental exposures were shown to have an impact on cell life functions, although the research in this direction is scarce. Mice offspring exposed in utero to high levels of particulate matter (PM) showed significantly suppressed splenocyte proliferation (Hong et al. 2013). PM was shown to have an adverse impact on the respiratory system leading to cytotoxic and inflammatory effects, as measured by the cell proliferation MTT test (Orona et al. 2014). Another study (Schaub et al. 2009) showed a decreased lymphocytes proliferation in cord blood taken in mothers exposed to farming during pregnancy. The studies demonstrated a possibility of a modulating effect of environmental factors on fetus cells.

The possible linkage between impaired cell malfunctioning and environment might explain an abundant research connecting environmental pollution with an

\footnotetext{
*Correspondence: novack@bgu.ac.il

${ }^{8}$ Department of Public Health, Ben-Gurion University of the Negev, P.O.B.

653, Beersheba, Israel

Full list of author information is available at the end of the article
}

increased neonatal morbidity worldwide, e.g. birth defects (Padula et al. 2013a, b; Vinikoor-Imler et al. 2013; Ramakrishnan et al. 2013; Agay-Shay et al. 2013a, b; Fung et al. 2013; Nieuwenhuijsen et al. 2013).

The association between cell function and morbidity (specifically, malformations) has been examined in relation to a spectrum of small eye phenotypes in Zebrafish embryos (French et al. 2013). Hypersecretion and oxidative markers of lung injury in mice were linked to environmental exposure to Ozone (O3) (Cho et al. 2013).

This concept, however, is rarely discussed in epidemiological literature.

In the current investigation we aimed to assess the properties of cell proliferation of lymphocytes in umbilical cord blood of pregnant women in relation to hazardous environments in their household and outdoor pollution. We studied the population of Arab-Bedouin pregnant women characterized by excessive rates of major congenital malformations (CM) and other morbidity and mortality, as previously shown in a number of semi-ecological investigations (Bentov et al. 2006; Sarov et al. 2008).

\section{望 Springer}

(c) 2015 Novack et al. This article is distributed under the terms of the Creative Commons Attribution 4.0 International License (http://creativecommons.org/licenses/by/4.0/), which permits unrestricted use, distribution, and reproduction in any medium, provided you give appropriate credit to the original author(s) and the source, provide a link to the Creative Commons license, and indicate if changes were made. 
The Arab-Bedouin population is exposed to multiple hazardous factors. It is featured by the lowest socio-economic level (Abu-Saad 1998), a high rate of unemployment, low educational level (The Central Bureau of Statistics 2015), and frequent consanguineous marriages (45\%) (Jaber et al. 1994). This population resides in permanent housing, but frequently-in traditional tribal settlements-temporary pre-fabricated shacks or tents. Cooking and heating is often provided by open fire. Smoking is very common among Bedouin men (AbuSaad 1998). The study area is exposed to frequent dust storms in winter (Ganor 1991; Krasnov et al. 2014; Dayan et al. 2011). A local industrial park (IP) presents an additional potential health hazard, whereas residence in its close proximity was associated with higher rates of major $\mathrm{CM}$, independent of consanguinity in the family (Bentov et al. 2006).

In our study we tested the hypothesis that cell proliferation of lymphocytes in umbilical cord blood of pregnant women is associated with various environmental exposures.

Most of the research performed currently in environmental health is focused on ambient measurements of exposure or on in vitro studies of animals' cells. (Cho et al. 2013; Pires et al. 2011) However it is the human individual measurement of exposure that is mostly desired for an accurate estimation of the environmental impact. The high cost of biomarkers and their complexity make them unavailable for a large scale study. Umbilical cord is the material which has a potential of a non-invasive testing procedure (always available at delivery) and representing simultaneously maternal and fetal organisms. With this in mind, investigation of the properties of cord blood might enable an accurate estimation of exposure in future environmental research.

\section{Methods}

We enrolled mothers of Arab-Bedouin origin 18 years of age and older and their offspring delivered by singleton birth in Soroka University Medical Center (SUMC) in Beer-Sheva, the only medical center providing tertiary services to the residents in the study area of about $600,000-700,000$ residents in southern Israel. We excluded neonates with gestational age under 22 weeks or weight under $500 \mathrm{~g}$, to avoid serious morbidity in the study population most possibly unrelated to the environmental exposures. During June 2012-December 2013, every eligible mother was approached upon her admission to the obstetric emergency room, and was invited to participate in the study, during the day-working hours.

We used the MTT (3-(4,5-dimethylthiazol-2-yl)-2,5-diphenyltetrazolium bromide) Cell Proliferation Assay (Yellow MTT), which measured a sustainability of cells in umbilical cord. Specifically, the assay tests the proliferation reflecting the mitochondrial function, such as energy metabolism, control of apoptosis and has its own genetic material in addition to nucleus with high ability of generation of reactive oxygen species (ROS) (Byun et al. 2013). The test is considered to be a valuable tool in a wide range of research areas, assessing drug sensitivity, cytotoxicity, response to growth factors, and cell activation (Mosmann 1983). A linear relationship between cell number and absorbance is established for each cell, enabling accurate and straight-forward quantification of changes in proliferation. In the present study the cells were isolated from blood by Ficoll-Histopaque density gradient. As the next step, we used the overall T lymphocyte cells of the umbilical cord blood known to be stimulated by Phytohemagglutinin (PHA). The Optical Density (OD) values of MTT were assessed by the enzyme-linked immunosorbent assay (ELISA). To obtain the cell proliferation ratio, the $\mathrm{T}$ cells stimulated by PHA were further divided by an estimate of a natural not-stimulated proliferation of the same cells within the same individual (American Type Culture Collection 2011).

The assay, however, has its limitations since the results might be affected by a physiological state of cells and variance in mitochondrial dehydrogenase activity in different cell types (Cell Proliferation Assay 2015) as well as viral morbidity and smoking (Li et al. 2013; Cheng et al. 2012).

Umbilical cord blood samples were collected at delivery and stored at $+2 / 3^{\circ} \mathrm{C}$ for up to $48 \mathrm{~h}$ before they were processed (Cell Proliferation Assay 2015) for testing.

\section{Assessment of environmental factors}

Information on subjects' addresses at pregnancy, potential household exposures and demographical status was collected in an interview during hospitalization. The interview included questions regarding subjects' exact addresses at pregnancy, socio-economic status, family history of malformations, consanguineous marriages, parental exposure to environmental or occupational factors, parental health behavior and health status during the pregnancy and recent medical problems.

An exposure to prevailing winds from the local IP was established in a previous ecological study in the area (Druyan et al. 1986), which remained stable over years. (Cedar Lake Ventures Inc 2014) Clinical information was retrieved from the hospital Admission-Transfer-Discharge (ATD) database.

\section{Statistical analysis}

Continuous data were presented as mean \pm standard deviation (SD), median, range and compared between subgroups by $\mathrm{t}$ test or Mann-Whitney. Categorical data 
were presented as proportions and compared using Chi Square or Fisher exact tests. CP ratio-the main outcome variable-was log-transformed and presented as geometric mean and the 95\% confidence interval (CI). The $\mathrm{CP}$ ratio was compared between two subgroups using a ratio $t$ test, and three or more subgroups using log-normal regression model. For the multivariable analysis of $\mathrm{CP}$ ratio readings the log-normal regression model was used, which provided estimates of prevalence ratios (PR) representing the multiplicative difference in $\mathrm{CP}$ ratio from the reference category. The choice of the final list of covariates in the reduced and final model was based on the findings of the univariate analysis ( $p$ value $<0.2$ ), potential confounding of other covariates and statistical significance in the model ( $\mathrm{p}$ value $<0.10$ ). The significance level in the multivariable analysis was set to $10 \%$ due to the relatively small sample size.

The written informed consent from subjects participating in the study was received prior to conducting the study. The study has been reviewed and approved by ethics committee (IRB) of the SUMC (\#5017).

\section{Results}

Overall 346 women were enrolled in the study. The questionnaires were collected for 286 of the 346 enrolled women $(82.7 \%)$, whereas 60 women without a questionnaire could not be reached by the interviewers due to early discharge and/or frequently on weekends. These women were 1 year older, resided closer to the IP and their offspring weighted $200 \mathrm{~g}$ more than the rest of the sample with questionnaires.

The mean $( \pm \mathrm{sd})$ of the CP ratio was $2.46( \pm 1.31)$, median 2.15, within the range $0.71-8.7$ (Fig. 1). The

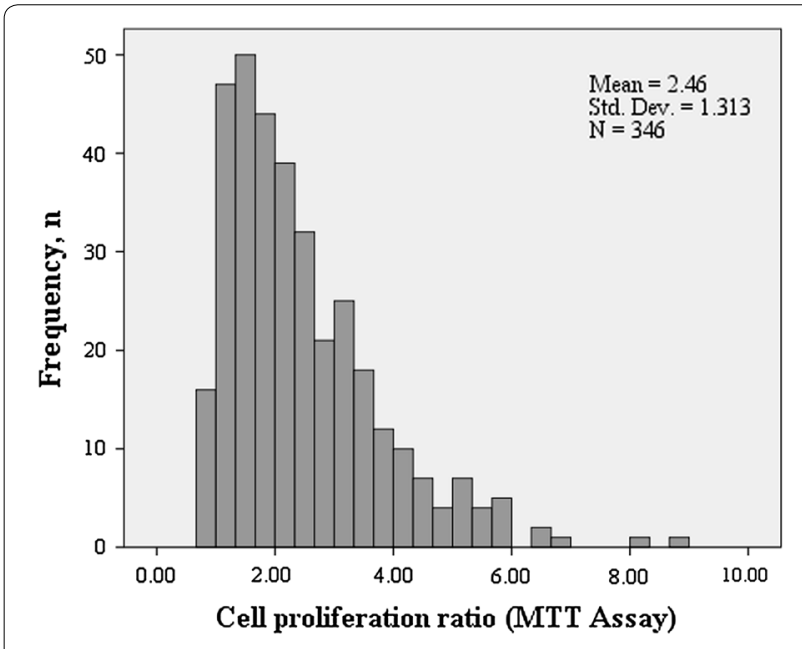

Fig. 1 Distribution of cell proliferation values in the study population. geometric mean of CP ratio was 2.17, with 95\% CI 2.06; 2.29 . The ratio was further investigated by quartiles, broken by $1.48,2.15$ and 3.15 , corresponding to the 25 th, 50th and 75th percentiles, and as log-transformed continuous variable.

The women were on average $27.3 \pm 5.9$ years old and median 26 years. For $30.5 \%$ of women it was the first delivery and $22.7 \%$ - had a history of more than 6 deliveries. About $10 \%$ of the women had a record of lack of prenatal care (LOPC) during pregnancy, usually for older women, and half of them (140/278) reported being married to a relative, usually (in $77.6 \%$ ) to a first-degree relative. Smoking of a husband was very frequent (94.9\%, 261/275).

The demographical factors, including consanguineous marriages, did not impact the $\mathrm{CP}$ ratio (Table 1 ). Some medical conditions, like a recommendation for abortion of the current delivery, was associated with lower CP ratio ( $\mathrm{GM}$ of $\mathrm{CP}=1.43$ in women with recommendation vs. 2.20 in women without, $\mathrm{p}$ value $=0.016)$. The history of repeated abortions and self-reported complications in pregnancy had only a borderline tendency towards lower values (p values 0.092 and 0.091 , respectively). Lower levels of CP ratio were also detected in umbilical cord of fetuses exposed to parental smoking, however this finding was of borderline significance, as well (0.105). Two mothers with the chronic hypertension diagnosis had high $\mathrm{CP}$ ratio $(\mathrm{GM}=2.81$, compared to $\mathrm{GM}=2.16$ in the study sample, $\mathrm{p}$ value $=0.024)$.

About 25\% of women reported living in a shack or tent $(69 / 286)$ (Table 2). Residing in a multi-story building yielded lower levels of $\mathrm{CP}(\mathrm{GM}=1.99$, $\mathrm{p}$ value $=0.052)$ compared to others. Above $89 \%$ of the study participants complained on exposure to dust and $55.6 \%$ reported car usually parked next to their house as a disturbing factor, which was more prevalent in women with higher cell proliferation ( $\mathrm{p}$ value $=0.052$ ), however this association was not linear ( $p$ value $=0.297$ ). Usage of open fire was expectantly high for heating (10.1\%) and cooking (74.5\%), but showed no impact on cell proliferation.

Women with CP ratio above median were more frequently residing in the direction of prevailing wind from the local IP compared to others (26.0 vs. $14.4 \%$, $\mathrm{p}$ value $=0.008, \mathrm{p}$ value for trend $=0.008)$, however the proximity to the IP made no difference on CP values. Delivery in fall or winter (September thru February), was more frequent for higher levels of proliferation (above median, 78.6\%) compared to lower levels of this biomarker, featured by less deliveries in a colder season $(66.5 \%)$ ( $p$ value $=0.011)$. Of note, the cold season is the one characterized by more frequent winds from the IP.

Noteworthy, complaints on noise featured women with lower $\mathrm{CP}$ ratio $(\mathrm{GM}=1.78$ vs. $\mathrm{GM}=2.20$ in the rest of 


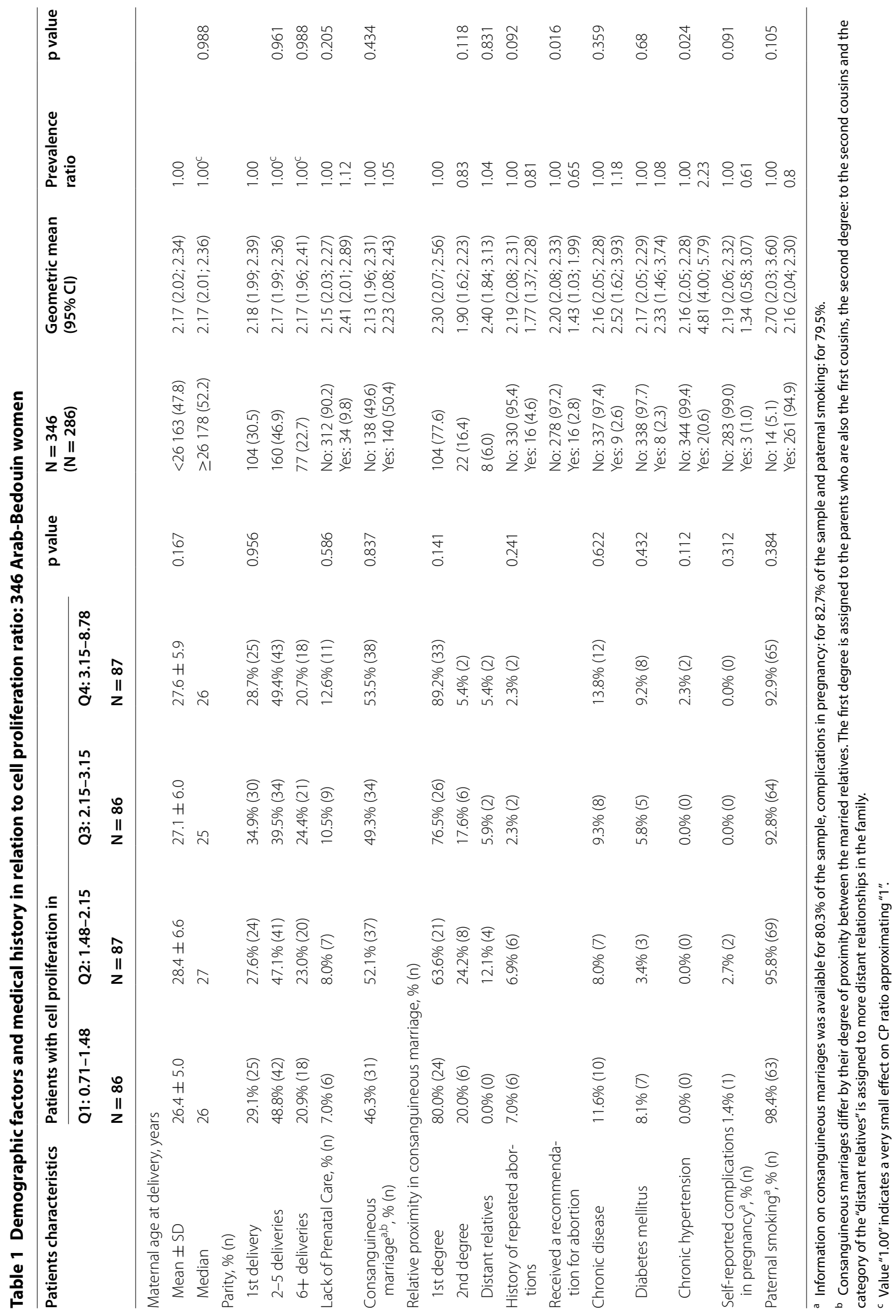


Table 2 Environmental Factors in relation to cell proliferation ratio: 346 Bedouin Women

\begin{tabular}{|c|c|c|c|c|c|c|c|c|c|}
\hline \multirow{3}{*}{$\begin{array}{l}\text { Environmental } \\
\text { factors }^{\mathrm{a}}\end{array}$} & \multicolumn{4}{|c|}{ Patients with proliferation in } & \multirow[t]{3}{*}{ p value } & \multirow{3}{*}{$\begin{array}{l}N=346 \\
(N=286)\end{array}$} & \multirow{3}{*}{$\begin{array}{l}\text { Geometric } \\
\text { mean } \\
(95 \% \mathrm{CI})\end{array}$} & \multirow{3}{*}{$\begin{array}{l}\text { Prevalence } \\
\text { ratio }\end{array}$} & \multirow[t]{3}{*}{$\mathrm{p}$ value } \\
\hline & Q1: 0.71-1.48 & Q2: $1.48-2.15$ & Q3: 2.15-3.15 & Q4: 3.15-8.78 & & & & & \\
\hline & $\begin{array}{l}N=86 \\
(N=69)^{a}\end{array}$ & $\begin{array}{l}N=87 \\
(N=74)^{a}\end{array}$ & $\begin{array}{l}N=86 \\
(N=70)^{a}\end{array}$ & $\begin{array}{l}N=87 \\
(N=73)^{a}\end{array}$ & & & & & \\
\hline \multicolumn{10}{|c|}{ Type of a house, \% (n) } \\
\hline Shack/tent & $21.7 \%(15)$ & $21.6 \%(16)$ & $28.6 \%(20)$ & $24.7 \%(18)$ & 0.147 & $69(24.6)$ & $2.18(1.95 ; 2.44)$ & 1.00 & \\
\hline $\begin{array}{l}\text { One-story } \\
\text { building }\end{array}$ & $42.0 \%(29)$ & $47.3 \%(35)$ & $41.4 \%(29)$ & $54.8 \%(40)$ & & $133(47.5)$ & $2.30(2.10 ; 2.51)$ & 0.96 & 0.534 \\
\hline $\begin{array}{r}\text { Multi-story } \\
\text { building }\end{array}$ & $33.3 \%(23)$ & $28.4 \%(21)$ & $28.6 \%(20)$ & $19.2 \%(14)$ & & $78(27.9)$ & $1.99(1.78 ; 2.23)$ & 0.87 & 0.052 \\
\hline \multicolumn{10}{|c|}{ Environmental factors reported as disturbing, \% (n) } \\
\hline Dust & $87.0 \%(60)$ & $91.9 \%(68)$ & $87.1 \%(61)$ & $91.8 \%(67)$ & 0.627 & $\begin{array}{l}\text { No: } 30(10.5) \\
\text { Yes: } 256(89.5)\end{array}$ & $\begin{array}{l}2.09(1.76 ; 2.48) \\
2.18(2.05 ; 2.32)\end{array}$ & $\begin{array}{l}1.00 \\
1.05\end{array}$ & 0.634 \\
\hline Mosquitoes & $91.3 \%(63)$ & $86.5 \%(64)$ & $92.9 \%(65)$ & $87.7 \%(64)$ & 0.561 & $\begin{array}{l}\text { No: } 30 \text { (10.5) } \\
\text { Yes: } 256(89.5)\end{array}$ & $\begin{array}{l}2.38(1.96 ; 2.88) \\
2.15(2.02 ; 2.29)\end{array}$ & $\begin{array}{l}1.00 \\
0.91\end{array}$ & 0.303 \\
\hline Noise & $10.1 \%(7)$ & $8.1 \%(6)$ & $2.9 \%(2)$ & $4.1 \%(3)$ & 0.247 & $\begin{array}{l}\text { No: } 268(93.7) \\
\text { Yes: } 18(6.3)\end{array}$ & $\begin{array}{l}2.20(2.08 ; 2.34) \\
1.78(1.42 ; 2.24)\end{array}$ & $\begin{array}{l}1.00 \\
0.81\end{array}$ & 0.082 \\
\hline Waste & $4.3 \%(3)$ & $10.8 \%(8)$ & $2.9 \%(2)$ & $9.6 \%(7)$ & 0.172 & $\begin{array}{l}\text { No: } 266(93.0) \\
\text { Yes: } 20(7.0)\end{array}$ & $\begin{array}{l}2.16(2.04 ; 2.30) \\
2.34(1.82 ; 3.00)\end{array}$ & $\begin{array}{l}1.00 \\
1.08\end{array}$ & 0.501 \\
\hline $\begin{array}{l}\text { Transport (fam- } \\
\text { ily cars) }\end{array}$ & $53.6 \%(37)$ & $44.6 \%(33)$ & $57.1 \%(40)$ & $67.1 \%(49)$ & 0.052 & $\begin{array}{l}\text { No: } 127(44.4) \\
\text { Yes: } 159(55.6)\end{array}$ & $\begin{array}{l}2.10(1.94 ; 2.28) \\
2.24(2.06 ; 2.43)\end{array}$ & $\begin{array}{l}1.00 \\
1.06\end{array}$ & 0.297 \\
\hline \multicolumn{10}{|c|}{ Type of heating, \% (n) } \\
\hline $\begin{array}{c}\text { Electric/AC/ } \\
\text { central } \\
\text { heating }\end{array}$ & $34.8 \%(24)$ & $48.6 \%(36)$ & $37.1 \%(26)$ & $34.2 \%(25)$ & 0.245 & $\begin{array}{l}\text { No: } 175 \text { (61.2) } \\
\text { Yes: } 111(38.8)\end{array}$ & $\begin{array}{l}2.19(2.03 ; 2.37) \\
2.14(1.96 ; 2.34)\end{array}$ & $\begin{array}{l}1.00 \\
0.98\end{array}$ & 0.703 \\
\hline $\begin{array}{l}\text { Stove with } \\
\text { chimney }\end{array}$ & $10.1 \%(7)$ & $9.5 \%(7)$ & $10.0 \%(7)$ & $6.8 \%(5)$ & & $\begin{array}{l}\text { No: } 260(90.9) \\
\text { Yes: } 26(9.1)\end{array}$ & $\begin{array}{l}2.19(2.05 ; 2.33) \\
2.06(1.76 ; 2.41)\end{array}$ & $\begin{array}{l}1.00 \\
0.94\end{array}$ & 0.571 \\
\hline $\begin{array}{l}\text { Stove without } \\
\text { chimney }\end{array}$ & $43.5 \%(30)$ & $25.7 \%(19)$ & $38.6 \%(27)$ & $46.6 \%(34)$ & & $\begin{array}{l}\text { No: } 176(61.5) \\
\text { Yes: } 110(38.5)\end{array}$ & $\begin{array}{l}2.15(2.01 ; 2.30) \\
2.20(1.99 ; 2.47)\end{array}$ & $\begin{array}{l}1.00 \\
1.03\end{array}$ & 0.581 \\
\hline Open fire & $7.2 \%(5)$ & $10.8 \%(8)$ & $10.0 \%(7)$ & $12.3 \%(9)$ & & $\begin{array}{l}\text { No: } 257 \text { (89.9) } \\
\text { Yes: } 29(10.1)\end{array}$ & $\begin{array}{l}2.16(2.03 ; 2.29) \\
2.14(1.95 ; 2.80)\end{array}$ & $\begin{array}{l}1.00 \\
1.08\end{array}$ & 0.422 \\
\hline $\begin{array}{l}\text { Cooking on } \\
\text { open fire, } \\
\%(n)\end{array}$ & $76.8 \%(53)$ & $67.6 \%(50)$ & $74.3 \%(52)$ & $79.5 \%(58)$ & 0.39 & $\begin{array}{l}\text { No: } 73(25.5) \\
\text { Yes: } 213(74.5)\end{array}$ & $\begin{array}{l}2.11(1.89 ; 2.35) \\
2.20(2.05 ; 2.36)\end{array}$ & $\begin{array}{l}1.00 \\
1.04\end{array}$ & 0.525 \\
\hline $\begin{array}{l}\text { Usage of pesti- } \\
\text { cides, } \%(n)\end{array}$ & $91.3 \%(63)$ & $86.5 \%(64)$ & $90.0 \%(63)$ & $86.3 \%(63)$ & 0.723 & $\begin{array}{l}\text { No: } 33(11.5) \\
\text { Yes: } 253(88.5)\end{array}$ & $\begin{array}{l}2.42(2.03 ; 2.89) \\
2.14(2.02 ; 2.28)\end{array}$ & $\begin{array}{l}1.00 \\
0.88\end{array}$ & 0.186 \\
\hline $\begin{array}{l}\text { Using water } \\
\text { containers, } \\
\%(n)\end{array}$ & $91.3 \%(63)$ & $86.5 \%(64)$ & $92.9 \%(65)$ & $93.2 \%(68)$ & 0.47 & $\begin{array}{l}\text { No: } 26(9.1) \\
\text { Yes: } 260(90.9)\end{array}$ & $\begin{array}{l}2.18(1.79 ; 2.66) \\
2.17(2.04 ; 2.31)\end{array}$ & $\begin{array}{l}1.00 \\
1.00\end{array}$ & 0.974 \\
\hline \multicolumn{10}{|c|}{ Type of water container, \% (n) } \\
\hline Water tank & $26.1 \%(18)$ & $33.8 \%(25)$ & $28.6 \%(20)$ & $19.2 \%(14)$ & 0.109 & $\begin{array}{l}\text { No: } 209 \text { (73.1) } \\
\text { Yes: } 77(26.9)\end{array}$ & $\begin{array}{l}2.22(2.06 ; 2.38) \\
2.07(1.87 ; 2.28)\end{array}$ & $\begin{array}{l}1.00 \\
0.93\end{array}$ & 0.927 \\
\hline $\begin{array}{l}\text { Small contain- } \\
\quad \text { ers }\end{array}$ & $60.9 \%(42)$ & $47.3 \%(35)$ & $57.1 \%(40)$ & $63.0 \%(46)$ & & $\begin{array}{l}\text { No: } 123 \text { (43.0) } \\
\text { Yes: } 163(57.0)\end{array}$ & $\begin{array}{l}2.15(1.98 ; 2.33) \\
2.19(2.02 ; 2.38)\end{array}$ & $\begin{array}{l}1.00 \\
1.02\end{array}$ & 0.728 \\
\hline Barrel & $4.3 \%(3)$ & $5.4 \%(4)$ & $7.1 \%(5)$ & $11.0 \%(8)$ & & $\begin{array}{l}\text { No: } 266 \text { (93.0) } \\
\text { Yes: } 20(7.0)\end{array}$ & $\begin{array}{l}2.16(2.03 ; 2.29) \\
2.45(1.98 ; 3.02)\end{array}$ & $\begin{array}{l}1.00 \\
1.14\end{array}$ & 0.27 \\
\hline $\begin{array}{l}\text { Resides in direc- } \\
\text { tion of prevail- } \\
\text { ing wind from } \\
\text { IP, \% (n) }\end{array}$ & $14.0 \%(12)$ & $14.9 \%(13)$ & $23.3 \%(20)$ & $28.7 \%(25)$ & 0.046 & $\begin{array}{l}\text { No: } 276 \text { (79.8) } \\
\text { Yes: } 70(20.2)\end{array}$ & $\begin{array}{l}2.11(1.99 ; 2.24) \\
2.44(2.16 ; 2.74)\end{array}$ & $\begin{array}{l}1.00 \\
1.16\end{array}$ & 0.03 \\
\hline $\begin{array}{l}\text { Resides within } \\
10 \mathrm{~km} \text { from } \mathrm{IP}^{\mathrm{a}} \text {, } \\
\%(\mathrm{n})^{\mathrm{b}}\end{array}$ & $7.2 \%(6)$ & $5.8 \%(5)$ & $9.5 \%(8)$ & $8.3 \%(7)$ & 0.827 & $\begin{array}{l}\text { No: } 311(92.3) \\
\text { Yes: } 26(7.7)\end{array}$ & $\begin{array}{l}2.16(2.05 ; 2.29) \\
2.24(1.85 ; 2.71)\end{array}$ & $\begin{array}{l}1.00 \\
1.03\end{array}$ & 0.741 \\
\hline $\begin{array}{l}\text { Delivery in fall or } \\
\text { winter, } \%(n)^{b, c}\end{array}$ & $68.6(59)$ & $64.4(56)$ & $75.6(65)$ & $82.5(71)$ & 0.056 & $\begin{array}{l}\text { No: } 95 \text { (24.5) } \\
\text { Yes: } 251 \text { (72.5) }\end{array}$ & $\begin{array}{l}2.00(1.83 ; 2.19) \\
2.24(2.10 ; 2.39)\end{array}$ & $\begin{array}{l}1.00 \\
1.12\end{array}$ & 0.06 \\
\hline
\end{tabular}

a Number of available questionnaires.

b Data derived from a database for all subjects.

c Fall and winter period was defined as months from September through February. 
the sample), however this finding was only borderline significant ( $\mathrm{p}$ value $=0.082$ ).

Multivariable analysis indicated an independent positive association of CP with the residence in the direction of the prevalent wind from the local IP ( $P R=1.17$, $\mathrm{p}$ value $=0.075)$, delivery between September-February $(\mathrm{PR}=1.15, \mathrm{p}$ value $=0.028)$, and a negative association with complaints on noise $(\mathrm{PR}=0.81$, $\mathrm{p}$ value $=0.075)$. All the parameters above were adjusted to each other and the history of repeated abortions, shown to be related to lower levels of CP (Table 3).

Overall, 6.6\% (23/346) of enrolled newborns were diagnosed with congenital malformations. Malformations of any type were not found related to the biomarker. Mothers of newborns with malformations had experienced more abortions in the past, compared to mothers of healthy newborns $(13.6$ vs. $4.6 \%$, p value $=0.009)$ (data not shown).

\section{Discussion}

In this investigation we examined an effect of environmental exposures on a biomarker of an impaired or altered cell functions in humans, specifically, cell proliferation.

Readings of $\mathrm{CP}$ were found reflective of environmental exposures. The direction of CP ratio change towards higher values or lower values depended on the type of the exposure and is quite intriguing. For instance, in the presence of most of the external environmental factors the CP ratio values were likely to be higher, e.g. residence downwind from the local IP or cold seasons. This finding was supported by a study in mice showing increased inflammatory processes in the animals' cells as a result of exposure to Ozone (Cho et al. 2013). However, the report on cytotoxicity in human alveolar epithelial cells following exposure to particles was not consistent as well, showing once reduced, increased or unchanged cell viability (Orona et al. 2014). The exposure to noise in our study had an opposite tendency of decreasing the $\mathrm{CP}$ ratio. This finding is reinforced by the report by Jáuregui-Huerta et al. (2011) on exposure of rats to environmental noise associated with decreased cell proliferation in the hippocampal formation.

In some instances, associations of environmental factors and $\mathrm{CP}$ in a univariate exploratory analysis did not follow a linear dose-response function, but rather a nonmonotonic dose response curves, e.g. exposure to family cars parked closely to the women's house was correlated with both, low and high CP ratio. This type of association, resembling a $U$-shape, is often described in epidemiology, as well (Vandenberg 2013).

Lower CP levels, indicating low cellular metabolic activity, were more likely to be reported in mothers with adverse obstetrical history, i.e. repeated abortions and self-reported complications. Romanelli et al. (2009) team also expected preeclampsia to be the negative regulator of cell proliferation.

To conclude our main findings, we can hypothesize that the $\mathrm{CP}$ ratio is differently affected by external and internal factors, whereas higher values probably indicated environmental exposures and lower values-maternal and possibly neonatal morbidity. The example of exposure to noise contradicts this logic, however. Nevertheless, the mechanism could not be affirmed with the small sample in the current investigation, but should be tested in future research.

The absence of statistically significant association of $\mathrm{CP}$ ratio with the neonatal health outcomes, specifically malformations could be explained by a relatively small sample. Furthermore, if lower $\mathrm{CP}$ is indeed related to the history of repeated abortions or other complications (as indicated in the study), the fetuses with serious impairments might have been aborted prior to their enrollment, which in turn would limit the $\mathrm{CP}$ range to relatively higher values and make the differences indistinguishable. Furthermore, the $\mathrm{CP}$ values at birth might be associated with the newborn morbidity as revealed further in life, which requires a longer follow-up.

Of note, we registered a very high percent of consanguineous marriages in the study population, especially for the 1st degree relatives. This estimate was expected in the current population and is supported by reports by Jaber et al. (1994).

The population-based setting of the study, in which the participants were not pre-selected by the choice of a hospital and laboratory personnel; using a questionnaire with detailed description of the women's household and individual factors; and the biomarker representing both-maternal and neonatal organisms-all these add to the validity of our findings.

Table 3 An effect of environmental factors on the cell proliferation, based on log-normal multivariate model

\begin{tabular}{|c|c|c|}
\hline Environmental factor & Ratio $^{a}[95 \%$ confidence interval $(\mathrm{CI})]$ & p value \\
\hline Complaint on noise $(n=18)$ vs. subjects not complaining on this factor $(n=268)$ & $0.82(0.65 ; 1.03)$ & 0.094 \\
\hline Living in a direction of a prevalent wind from local IP $(n=70)$ vs others $(n=216)$ & $1.18(1.03 ; 1.35)$ & 0.015 \\
\hline Delivery in fall-winter ${ }^{b}(n=201)$ vs. deliveries in spring-summer $(n=85)$ & $1.16(1.02 ; 1.31)$ & 0.024 \\
\hline
\end{tabular}

a Ratios represent the multiplicative difference in cell proliferation ratio from the reference category.

b Fall and winter period was defined as months from September through February. 
The study has its limitations.

- Timing of the cell proliferation measurement taken only at delivery and not measured during pregnancy imposes a limitation, especially for investigation of malformations, whereas an early pregnancy period would be the most relevant. However, if women do not change their residence throughout their pregnancy (as in our study population), their cell proliferation values might reasonably well reflect the environmental exposures we meant to capture in the analysis, after a necessary adjustment to seasonality.

- We did not interview all the women enrolled in the study and, therefore, missed information on household exposures for $17 \%$ of the study sample. Based on the hospital charts, these women were more frequently residing closer to the IP than women who were interviewed. Therefore, there is a possibility of a selection bias, which might have weakened associations obtained in the analysis.

- It is essential to stress that the MTT assay that reflects viable cell metabolism, providing only a general indication of a cell function (proliferation) per se. Therefore, in a future research using this assay, a cell genetic testing of micronucleus or DNA damage, should be considered for validation of the results.

- We did not find an association of CP ratio with residing within $10 \mathrm{~km}$ from the IP, however, testing for even higher proximity, e.g. $5 \mathrm{~km}$, was not feasible due to the small concentrations of the population within this radius from the IP. This limitation might have created a certain misclassification of exposure leading to the non-significant result.

In addition, severe cases of preterm deliveries ( $<22$ weeks $)$ and low-birth weight $(<500 \mathrm{~g})$ were not included in the current investigation, which might have resulted in a selection bias towards a healthier population. While most of extreme cases of morbidity were not related to environment, our exclusion criteria might have also excluded cases with extreme hazardous environment and hence, decreased the magnitude of associations of $\mathrm{CP}$ and environmental factors.

\section{Conclusions}

The study suggests that the cell proliferation is independently associated with some environmental exposures. A long-term follow-up investigation of the children is required to assess their cognitive development. Women presenting with low or high levels of $\mathrm{CP}$ ratio should be followed-up.

\section{Authors' contributions}

$L N, M E, S B, D L$ and $K I$ conceived of the study, suggested its design and drafted the manuscript. LN performed the statistical analysis. GE and VT carried out the cell proliferation tests and interpreted the laboratory finding, and ME supervised performance of the tests. YM coordinated the study and participated in its design. LD, HR, and DD participated in the enrolment of the study participants and contributed to the interpretation of results. All authors read and approved the final manuscript.

\section{Author details}

${ }^{1}$ Faculty of Health Science, Ben-Gurion University of the Negev, Beersheba, Israel. ${ }^{2}$ Genetic Institute, Soroka University Medical Center, Beersheba, Israel. ${ }^{3}$ Clinical Research Center, Soroka University Medical Center, Beersheba, Israel. ${ }^{4}$ Department of Neonatology, Soroka University Medical Center, Beersheba, Israel. ${ }^{5}$ Ultrasound Unit, Department of Obstetrics and Gynecology, Soroka University Medical Center, Beersheba, Israel. ${ }^{6}$ Obstetric Emergency Room and Delivery Wards, Soroka University Medical Center, Beersheba, Israel. ${ }^{7}$ Environmental Epidemiology Department, Ministry of Health, Jerusalem, Israel.

${ }^{8}$ Department of Public Health, Ben-Gurion University of the Negev, P.O.B. 653, Beersheba, Israel.

\section{Acknowledgements}

The authors would like to thank the medical personnel, nurses and doctors, of the Obstetrical Emergency Rooms and Delivery wards and the laboratory personnel of Genetic Institute laboratories in Soroka Medical Research Center, who hosted this research. Special thank you goes to Savyona Ben Ayun, Iris Raz, Alina Kopitman and Polina Katchko. We are grateful to our interviewers, Ada Algaar and Mirbat Alzaana, for their outstanding work. This study was supported by Grant no. 3-7298 from the Public Committee for Allocation of Estate Funds, Ministry of Health, Israel.

\section{Compliance with ethical guidelines}

\section{Competing interests}

The authors declare that they have no competing interests.

\section{Consent for publication}

The consent from subjects participating in the study was received prior to conducting the study. The study has been reviewed and approved by ethics committee (IRB) of the Soroka University Medical Center.

Received: 12 January 2015 Accepted: 3 July 2015

Published online: 24 July 2015

\section{References}

Abu-Saad I (1998) The influence of settlement on substance use and abuse among nomadic populations in Israel and Kenya. Center for Bedouin Studies and Development, Ben-Gurion University, Beer-Sheva

Agay-Shay K, Friger M, Linn S, Peled A, Amitai Y (2013a) Ambient temperature and congenital heart defects. Hum Reprod 28:2289-2297

Agay-Shay K, Friger M, Linn S, Peled A, Amitai Y, Peretz C (2013b) Air pollution and congenital heart defects. Environ Res 124:28-34

American Type Culture Collection ATCC (2011) MTT Cell Proliferation Assay. http://www.atcc.org/ /media/DA5285A1F52C414E864C966FD78C9A79. ashx. Accessed July 25, 2014

Bentov Y, Kordysh E, Hershkovitz R, Belmaker I, Polyakov M, Bilenko N et al (2006) Major congenital malformations and residential proximity to a regional industrial park including a national toxic waste site: an ecological study. Environ Health 5:8

Byun HM, Panni T, Motta V, Hou L, Nordio F, Apostoli P (2013) Effects of airborne pollutants on mitochondrial DNA methylation. Part Fibre Toxicol 10:18 
Cedar Lake Ventures Inc. (2014) WeatherSpark Beta: Average Weather For Negev, Israel. http://weatherspark.com/averages/32341/Negev-Israel. Accessed January 5, 2015

Cell Proliferation Assay (2015) Protocol Online. n.d. http://www.protocolonline.org/prot/Protocols/Cell-Proliferation-Assay-3443.html. Accessed January 5, 2015

Cheng YH, Huang SC, Lin CJ, Cheng LC, Li LA (2012) Aryl hydrocarbon receptor protects lung adenocarcinoma cells against cigarette sidestream smoke particulates-induced oxidative stress. Toxicol Appl Pharmacol 259:293-301

Cho HY, Gladwell W, Yamamoto M, Kleeberger SR (2013) Exacerbated airway toxicity of environmental oxidant ozone in mice deficient in Nrf2. Oxid Med Cell Longev 2013:254069

Dayan U, Erel Y, Shpund J, Kordova L, Wanger A, Schauer JJ (2011) The impact of local sources and meteorological factors on nitrogen oxide and particulate matter concentrations: a case study of the Day of Atonement in Israel. Atmos Environ 45:3325-3332

Druyan LM, Goldreich Y, Masimov Z (1986) Wind energy survey in the Negev (Israel). Appl Geogr 6:211-254

French CR, Stach TR, Lehmann OJ, Waskiewicz AJ (2013) Apoptotic and proliferative defects characterize ocular development in a microphthalmic BMP model. Investig Ophthalmol Vis Sci 54:4636-4647

Fung A, Manlhiot C, Naik S, Rosenberg H, Smythe J, Lougheed J et al (2013) Impact of prenatal risk factors on congenital heart disease in the current era. J Am Heart Assoc 2:e000064

Ganor E (1991) The composition of clay minerals transported to Israel as indicators of Saharan dust emission. Environ Atmos 25A:2657-2664

Hong X, Liu C, Chen X, Song Y, Wang Q, Wang P et al (2013) Maternal exposure to airborne particulate matter causes postnatal immunological dysfunction in mice offspring. Toxicology 306:59-67

Jaber L, Bailey-Wilson JE, Haj-Yehia M, Hernandez J, Shohat M (1994) Consanguineous matings in an Israeli-Arab community. Arch Pediatr Adolesc Med 148:412-415

Jáuregui-Huerta F, Garcia-Estrada J, Ruvalcaba-Delgadillo Y, Trujillo X, Huerta M, Feria-Velasco A et al. (2011) Chronic exposure of juvenile rats to environmental noise impairs hippocampal cell proliferation in adulthood. Noise Health 13:286-291

Krasnov H, Katra I, Koutrakis P, Friger MD (2014) Contribution of dust storms to PM10 levels in an urban arid environment. J Air Waste Manag Assoc 64(1):89-94

Li X, Peng B, Nie C, Shang P, Liu H (2013) Evaluation of the cytotoxicity of cigarette smoke total particulate matter using three in vitro assays and two types of cells. Toxicol Mech Methods 23:240-246

Mosmann T (1983) Rapid colorimetric assay for cellular growth and survival: application to proliferation and cytotoxicity assays. J Immunol Methods 65:55-63
Nieuwenhuijsen MJ, Dadvand P, Grellier J, Martinez D, Vrijheld M (2013) Environmental risk factors of pregnancy outcomes: a summary of recent meta-analyses of epidemiological studies. Environ Health 12:6

Orona NS, Astort F, Maglione GA, Saldiva PH, Yakisich JS, Tasat DR (2014) Direct and indirect air particle cytotoxicity in human alveolar epithelial cells. Toxicol In Vitro 28(5):796-802

Padula AM, Tager IB, Carmichael SL, Hammond SK, Yang W, Lurmann FW et al (2013a) Traffic-related air pollution and selected birth defects in the San Joaquin Valley of California. Birth Defects Res Part A Clin Mol Teratol 97:730-735

Padula AM, Tager IB, Carmichael SL, Hammond SK, Lurmann F, Shaw GM (2013b) The association of ambient air pollution and traffic exposures with selected congenital anomalies in the San Joaquin Valley of California. Am J Epidemiol 177:1074-1075

Pires A, de Melo EN, Mauad T, Nascimento Saldiva PH, de Siqueira Bueno HM (2011) Pre- and postnatal exposure to ambient levels of urban particulate matter $(\mathrm{PM}(2.5))$ affects mice spermatogenesis. Inhal Toxicol 23(4):237-245

Ramakrishnan A, Lupo PJ, Agopian AJ, Linder SH, Stock TH, Langlois PH et al (2013) Evaluating the effects of maternal exposure to benzene, toluene, ethyl benzene, and xylene on oral clefts among offspring in Texas: 1999-2008. Birth Defects Res A Clin Mol Ter 97:532-537

Romanelli V, Belinchón A, Campos-Barros A, Heath KE, García-Miñaur S, Martínez-Glez V et al (2009) CDKN1C mutations in HELLP/preeclamptic mothers of Beckwith-Wiedemann Syndrome (BWS) patients. Placenta 30(6):551-554

Sarov B, Bentov Y, Kordysh E, Karakis I, Bolotin A, Hershkovitz R et al (2008) Perinatal mortality and residential proximity to an industrial park. Arch Environ Occup Health 63:17-25

Schaub B, Liu J, Höppler S, Schleich I, Huehn J, Olek S et al (2009) Maternal farm exposure modulates neonatal immune mechanisms through regulatory T cells. Allergy Clin Immunol J 774e5:782e5

The Central Bureau of Statistics, Israel (2015) Demographic Characteristics. n.d. http://www1.cbs.gov.il/reader/cw_usr_view_Folder?ID=141. Accessed January 5, 2015

Vandenberg LN (2013) Non-monotonic dose responses in studies of endocrine disrupting chemicals: bisphenol a as a case study. Dose Response 7:259-276

Vinikoor-Imler LC, Davis JA, Meyer RE, Luben TJ (2013) Early prenatal exposure to exposure to air pollution and its associations with birth defects in a state-wide birth cohort from North Carolina. Birth Defects Res A Clin Mol Teratol 97:696-701

\section{Submit your manuscript to a SpringerOpen ${ }^{\circ}$ journal and benefit from:}

- Convenient online submission

- Rigorous peer review

- Immediate publication on acceptance

- Open access: articles freely available online

- High visibility within the field

- Retaining the copyright to your article

Submit your next manuscript at $>$ springeropen.com 